\title{
EVALUATING OUT-PLANTING SUCCESS AND MYCORRHIZAL STATUS OF ENDANGERED GEUM PECKII PURSH (ROSACEAE), THE EASTERN MOUNTAIN AVENS, IN NOVA SCOTIA
}

\author{
${ }^{1} \uparrow$ SARAH FANCY, ${ }^{1 *}$ JUAN C. LÓPEZ-GUTIÉRREZ, \\ ${ }^{1}$ ALLISON K. WALKER, ${ }^{2}$ DIANE LARUE, \\ ${ }^{3}$ ROBIN BROWNE \\ ${ }^{I}$ Department of Biology, Acadia University, Wolfville, NS \\ †Current Address: Dalhousie University \\ Faculty of Agriculture, Truro, NS \\ ${ }^{2}$ Mersey Tobeatic Research Institute, Kempt, NS \\ ${ }^{3} K$.C. Irving Environmental Science Centre and \\ Harriet Irving Botanical Gardens, Acadia University, Wolfville, NS
}

\begin{abstract}
Geum peckii (Rosaceae), the Eastern Mountain Avens, is a small herbaceous plant that is listed as endangered federally and provincially. In Canada, this species is found in bogs on Brier Island and Harris Lake, Digby County, Nova Scotia. The only other population outside of Canada is in New Hampshire (USA). To enhance conservation research of this species, a seed sample from the native species seed bank at Acadia University was used to establish a plant tissue culture of G. peckii plants. Survival of outplanted material was then assessed in both the greenhouse and the field. The field test site was within $20 \mathrm{~km}$ of the existing plant populations in Digby County. Our study also revealed that $G$. peckii grows in association with arbuscular mycorrhizal fungi (AMF). During out-planting, plants received a mycorrhizal inoculum with the goal of enhancing survival. We used either a commercial mycorrhizal inoculum, or a native inoculum. Control plants were left untreated. Survival was $97-100 \%$ among all the treatments by the end of the 2016 planting season. The results to date underscore the potential value of seed banking for protection of endangered native plant species. This study marks the first time in Nova Scotia that an endangered plant species has been successfully retrieved from seed bank storage, propagated by tissue culture, and out-planted back into a natural habitat.

Keywords: Conservation, endangered native species, Geum peckii, tissue culture propagation
\end{abstract}




\section{INTRODUCTION}

Geum peckii Pursh (Rosaceae), the Eastern Mountain Avens, is a small herbaceous plant listed as endangered federally and provincially (COSEWIC, 2010; Environment Canada, 2010). In Canada, this species is only found in bogs near sea level on Brier Island, and near Harris Lake on Digby Neck, both sites being in Digby County, Nova Scotia (Fig 1). Globally, the only other population is found in the White Mountains of New Hampshire, USA (COSEWIC, 2010; Environment Canada, 2010; LaRue, 2016a). A comprehensive count of the Brier Island population in 2012 and 2013 estimated the number of plants to be 6000 (LaRue, 2016a). Population counts since 1986 have shown a declining trend, although differences in counting methods have made determining exact numbers challenging (LaRue, 2016a). The largest Brier Island population in Big Meadow Bog has declined due to hydrological changes from a ditching attempt during the 1950's (COSEWIC, 2010; LaRue, 2016a). As the bog dried, sea gull nests and shrub encroachment have become threats contributing to the decline of this species (COSEWIC, 2010; LaRue, 2016a).

Global biodiversity is threatened in the current age of the Anthropocene, and seed banks are considered one of the most effective methods for ex situ conservation to help mitigate losses of plant biodiversity and prevent species extinctions (Maunder et al., 2004;

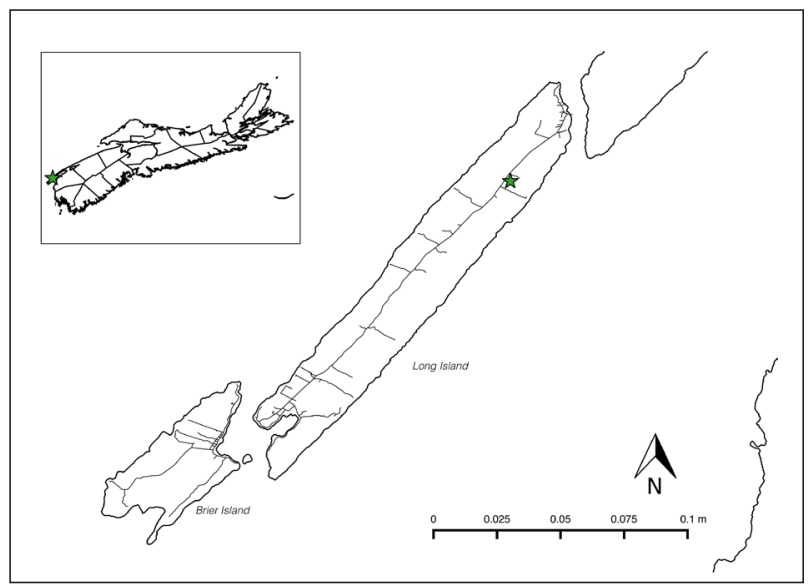

Fig 1 The field trial location on Long Island is indicated with a green star on the map. Native populations of G. peckii are found on Brier Island and at Harris Lake, the two landmasses on either side of Long Island, Nova Scotia. 
Bunn et al., 2007). The K.C. Irving Environmental Science Centre at Acadia University, Wolfville, Nova Scotia, is a research scale seed bank with the mandate to protect and preserve native species found in the Acadian Forest Region of Canada. Geum peckii is currently one species of interest. In 2014, seed was collected from the Big Meadow population on Brier Island (under NS DLF permit) and is currently stored in the seed bank.

The restoration efforts undertaken in this study for G. peckii are consistent with the Global Strategy for Plant Conservation targets for ex situ conservation of native endangered plants and align with the endorsed use of tissue culture techniques for conservation of endangered species (Convention on Biological Diversity, 2012; Rowntree et al., 2011). This provides the opportunity for producing large numbers of plants from a single seed for subsequent testing in conservation programs (Pence, 2011; Ayuso et al., 2019). However, tissue cultures lack the fungal and bacterial associates as sterile conditions are necessary (Kumar and Rao, 2012). The need for aseptic conditions leads to challenges when out-planting from tissue cultures (Chandra et al., 2010).

Arbuscular mycorrhizal fungi (AMF) are a group of obligate symbiotic fungi that form mutualistic associations with roots of over $80 \%$ of land plants (Smith and Read, 2008), but are not normally present under tissue culture conditions. AMF aid in survival and growth by providing water and nutrients to the plants in exchange for carbon (Smith and Read, 2008; Neuenkamp et al., 2018). It was hypothesized that the inoculation of AMF to the roots of tissue culture derived plantlets of $G$. peckii would improve out-planting success.

\section{METHODS}

\section{Stage 1: Establishment of a plant tissue culture population for testing}

To develop the tissue culture population for an out-planting study, a series of trials were completed using agar filled Petri Dishes to find appropriate seed sterilization and micro-propagation methods for this species (Adams 2016; Fancy, 2017) (data not shown). Tissue culture plants were maintained on media made by adding $2.2 \mathrm{~g} / \mathrm{L}$ Murashige and Skoog nutrients (Caisson Labs), 5.8g/L agar (Fisher Scientific) and $20 \mathrm{~g}$ sucrose in reverse osmosis water with $\mathrm{pH}$ adjusted to 5.8. Media 
was autoclaved for 15 minutes at $121^{\circ} \mathrm{C}$ at $15 \mathrm{PSI}$ and $45 \mathrm{~mL}$ of molten media was poured into a sterile culture jar (Sigma Aldrich). Preliminary trials were done by adding activated biochar (Novagreen Inc) at a rate of $250 \mathrm{mg} / \mathrm{L}$ to the standard media recipe before autoclaving (Moland et al., 2018). Visually, the use of activated biochar promoted more rapid growth of G. peckii in vitro (Fig 2). All plants used in the trial were grown in biochar amended media before transitioning out of tissue culture. The specific culture population used for the outplanting study was increased by dividing the plants monthly as their growth allowed. Plants were subsequently divided, and ID numbers were assigned, to allow the ability to trace the original parent seed.

\section{Stage 2: Plant hardening and AMF inoculum introduction}

\section{Plant Hardening}

Seventy-two of the most robust plants were chosen from the established tissue culture population for the field and greenhouse out-planting trials. The plants were split into two groups of 30, with 12 extra in case of initial die off. Twenty-two different parent seeds were represented in the field trial population and 18 in the greenhouse population. Subgroups for different treatments were then created, again based on evenly distributing plants from the same parent seed. There were three experimental groups tested in both the greenhouse and field trials. The first had a prepared native inoculum added (see below under AMF treatment), the second was a commercial inoculum (MykePro WP powder obtained from Premier Tech Biotechnologies, Riviere de Loup, Quebec), and the third control group was left untreated.

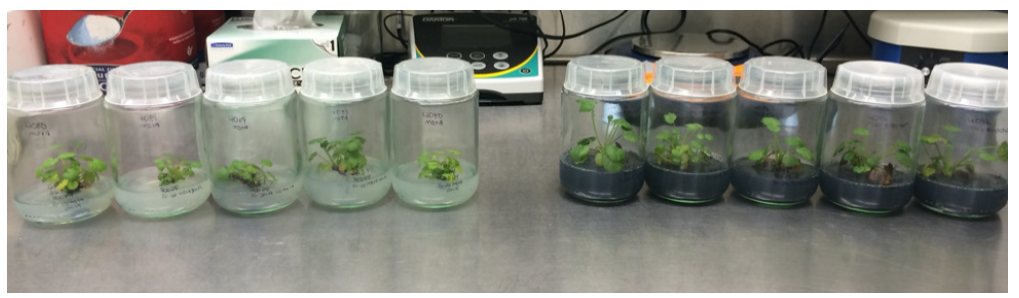

Fig 2 Tissue cultured Geum peckii in jar vessels shown with typical growth media (water agar, sucrose, MS nutrients) on the left and the same media with added activated biochar on the right. Visually, the biochar amended growth media provided increased plant vigor. All plants were grown in biochar amended media before transitioning out of tissue culture. 
For acclimatization of tissue culture plantlets to the greenhouse and field conditions, plantlets were first removed from culture medium and out-planted into $4 \mathrm{~cm} \times 4 \mathrm{~cm} \times 4 \mathrm{~cm}$ plastic germination cells with thoroughly wetted LP15 ProMix ${ }^{\mathrm{TM}}$ on 24 June 2016. Cells were placed into clear $30 \mathrm{~cm} \times 35 \mathrm{~cm}$ plastic boxes with drilled holes to allow some air exchange and water drainage. One box was used per treatment (prepared inoculum, commercial inoculum and untreated control) (Fig 3). These boxes were initially kept in the greenhouse at $20^{\circ} \mathrm{C}$, with average relative humidity near $70 \%$. No artificial lights were used to control photoperiod. After the hardening off period, plants were moved into the greenhouse trial on 11 July 2016, or the field trial on 18 July 2016.

\section{AMF Treatments}

Native AMF inoculum was produced using a modified trap pot method (Morton et al., 1993) by mixing 250g of Brier Island soil collected from under G. peckii with sterilized sand (1 hour at $121^{\circ} \mathrm{C}$ and $15 \mathrm{psi}$ ) in $2 \mathrm{~L}$ trap pots. Ten Zea mays (corn) seeds were sown and then thinned to 4 host plants per pot. Host plants were grown to flower in greenhouse conditions, watering as needed. After approximately 8 weeks of grow th watering was stopped. Once the plants dried out, the above ground biomass was removed and the soil along with the below ground biomass was kept as native AMF inoculum.

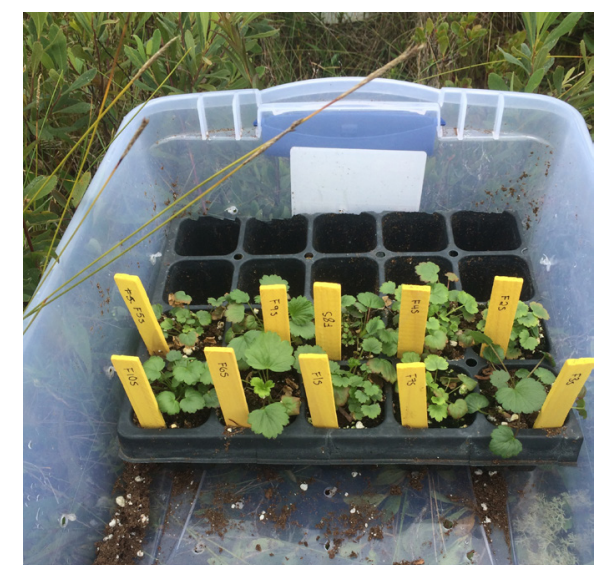

Fig 3 A G. peckii outplanting box filled with $244 \mathrm{~cm}$ X $4 \mathrm{~cm}$ cells containing the plants of one treatment. Two other similar boxes were made for the other treatments. 
Presence of AMF in roots of the host plant was confirmed via root clearing and staining (data not shown).

The commercial MykePro WP powder contained Glomus intraradices at a minimum concentration of 500 viable propagules per gram of powdered product. The concentration used was $0.6 \mathrm{~g}$ of powder per $200 \mathrm{~mL}$ of R.O. water. Three drops from a disposable glass pipette were put into each soil filled cell immediately before the plant was inserted. Concentrations of inocula used were adapted from Moland et al. (2018). The application rate of the prepared native inoculum was $10 \mathrm{~g}$ of homogenized trap soil per plant. A master mix was made by adding $250 \mathrm{~g}$ of soil from the trap pot to $267 \mathrm{~g}$ of LP15 ProMix ${ }^{\mathrm{TM}}$. This mixture was used to fill the 24 cells in the prepared inoculum box. Plants were kept moist by misting with R.O. water and time without the lids on boxes was gradually increased until permanent removal at two weeks.

\section{AMF Confirmation}

A trial was done to confirm that G. peckii can form associations with mycorrhizal fungi. Roots were examined from three ex situ plants grown in the K.C. Irving Centre Experimental Gardens at Acadia University. They were collected and analyzed for presence of AMF under a compound light microscope following the ink-vinegar staining method of Vierheilig et al. (1998). These plants originated from seed obtained from a Brier Island population, as part of preliminary germination tests conducted by LaRue (2016b).

\section{Stage 3: Out-planting trials \\ Greenhouse Out-planting}

The greenhouse trial was completed in a controlled environment phytotron room at the K.C. Irving Centre, Acadia University. After hardening off, plants were transferred to plastic greenhouse pots $(10 \mathrm{~cm} \times 10 \mathrm{~cm} \times 9 \mathrm{~cm})$ filled with moist LP15 ProMix ${ }^{\top \mathrm{M}}$. All the substratum in the original cells was transferred to the larger pots. Thirty plants were transferred to the greenhouse trial: 10 treated with native AMF inoculum, 10 with commercial AMF inoculum and 10 with no AMF inoculum. Plants were watered regularly with R.O. water and rotated on the bench daily to account for differences in light intensity, temperature gradients and air flow. No fertilizer was added to be consistent with the field population and the plants remained vigorous. Between July 11 and September 23, the greenhouse 
minimum temperature was $17^{\circ} \mathrm{C}$ and the maximum was $20^{\circ} \mathrm{C}$, with average relative humidity near $70 \%$ using natural day/night lighting.

\section{Field Out-planting}

The field trial was established in the Balancing Rock Bog on July 18, 2016, 19T $0720358 \mathrm{~N}, 4916242 \mathrm{E}$ within $20 \mathrm{~km}$ of the native G. peckii populations (Fig 1). The Balancing Rock Bog is on Long Island, Digby County, Nova Scotia and has similar habitat characteristics in terms of hydrology and plant species to the populations on Brier Island (Dr. Nick Hill, personal communication, June 11, 2016). Geum peckii is not known to occur naturally on Long Island (COSEWIC, 2010). This location was chosen in accordance with NS DLF to avoid any potential risk to the existing natural populations of G. peckii on Brier Island. A permit was granted by NS DLF to proceed with the trial. A $2 \mathrm{~m} \times 2 \mathrm{~m}$ plot was marked off with $3630 \mathrm{~cm}$ x $30 \mathrm{~cm}$ cells (Fig 4). Plants were randomized when planting into the grid. Any substrate that did not come out with the plug was first placed into the hole made in the sphagnum layer before the plant was added. A total of 30 plants were transferred to the field, 10 treated with native AMF inoculum, 10 with commercial AMF inoculum and 10 with no AMF inoculum.

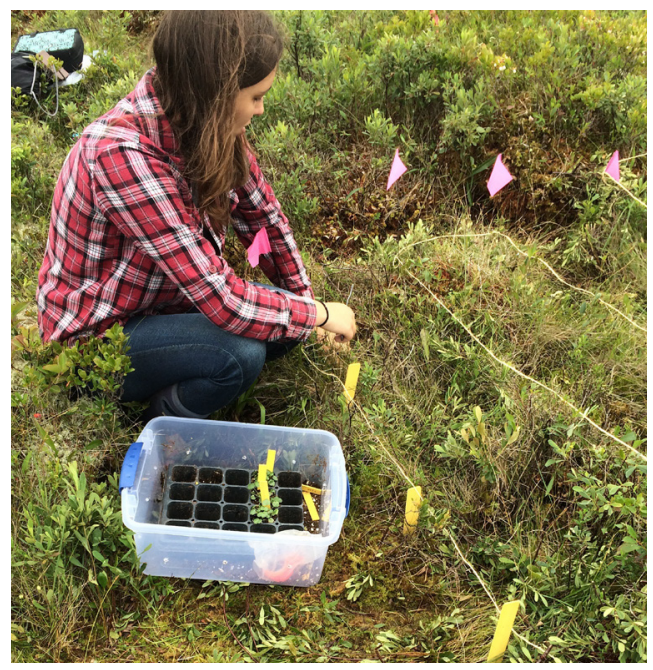

Fig 4 The author transplanting G. peckii into the grid in the Balancing Rock Bog on Long Island, Nova Scotia. 


\section{Stage 4: Growth monitoring and analysis \\ Plant Growth}

For nine weeks after planting, weekly observations were made on both the greenhouse and field populations. These observations included: number of brown leaves, number of green leaves, length of longest petiole, largest leaf length by width, and degree of leaf reddening. Leaf reddening was used as a visual parameter of stress level. The redness of leaves was ranked with scores from 1 (no redness) to 5 (over $95 \%$ of leaf surface red tinged). At the end of the growth period, roots from five G. peckii plants within the greenhouse population were sampled to determine of AMF colonization. Field plants were not sampled to avoid stressing the population. Prepared roots were observed with a compound light microscope on slides with equidistant horizontal lines. Presence/absence counts were done at each root-line intersection. To determine percent AMF root colonization, 100 crosses were analyzed per sample (Giovanetti and Mosse, 1980).

\section{Statistical Analyses}

GraphPad Prism version 7.0 was used for all statistical analyses. Data from observations of field and greenhouse plants were examined by two-way repeated measures ANOVA to assess differences among mycorrhizal treatments at two timepoints $(\mathrm{p}=0.05)$. Two-way repeated measures ANOVA was also completed to assess differences in out-plant success in relation to the parent seed. A t-test $(\mathrm{p}=0.05)$ was done to show statistical differences among plant growth in the greenhouse and field environments.

\section{RESULTS AND DISCUSSION}

\section{Plant survival following out-planting}

From July 18 to September 17, 2016, all plants (30) in the field and 29 in the greenhouse survived. The greenhouse plants grew larger than the field counterparts, possibly due to differences in temperature, moisture conditions and light intensity (Fig 5). On average, the length by width of leaves, and petiole length, was $57 \%$ and $61 \%$ larger in the greenhouse plants at the end of data collection. During the dry part of the summer, depth to water table was recorded as $78 \mathrm{~cm}$ below the bog surface; this level characterized the bog as a dry bog 
for G. peckii habitat (Poirier, 2016). Plants in the field were subject to herbivory over the summer. From August to September 2016, 18 of 30 plants showed signs of herbivory, although never more than 5 leaves per plant were involved (data not shown). Herbivory did not appear to correlate with a decrease in plant vigor.

The out-plant survival rates in this study were high compared to previous greenhouse out-plant trials with this species (Fancy, 2017). Factors such as size of plants at out-planting and duration in tissue culture under nutrient rich conditions may have been involved and merit further attention. The plantlets in the current study were grown in the presence of activated biochar in tissue culture, which may have exerted a beneficial effect (Moland et al., 2018). No significant differences were found between the parent seed and the vigor of any individual plant at $\mathrm{p}=0.05$. The success of a plant appeared have no correlation with the parent seed from which it originated (data not shown).

\section{Plant Growth and AMF Associations}

Plants in the greenhouse and field populations grew very well during their first season. There was an increase in the number of leaves, length and width of the largest leaf, and petiole length over the course of the nine week observations. The plants in the greenhouse grew larger than the field counterparts, with some individual leaves reaching length by width of $80 \mathrm{~mm} \times 62 \mathrm{~mm}$, while in the field the maximum was $40 \mathrm{~mm} \times 30 \mathrm{~mm}$. The difference in growth among the field and greenhouse grown plants was statistically significant when length and width of largest leaves and the petiole length were considered (Fig 5). In addition to size differences, the majority of field plants had various degrees of reddening, but none of the greenhouse plants showed reddening at the end of the trial. The most vigorous greenhouse plants increased their leaf width by more than $50 \mathrm{~mm}$ over the growth season. The size of $G$. peckii leaves in this trial fall within the range found in native populations where the width of the largest leaf on a single rosette varied from $15 \mathrm{~mm}$ to $150 \mathrm{~mm}$ (LaRue, unpublished data, 2016).

Two-way repeated measures ANOVAs were completed on only the first and last day of observations in both the field and greenhouse population to minimize the variable effect of individual plant growth. Results of the two-way repeated measure ANOVAs of the first and last day parameters are displayed in Fig 6 for the greenhouse 


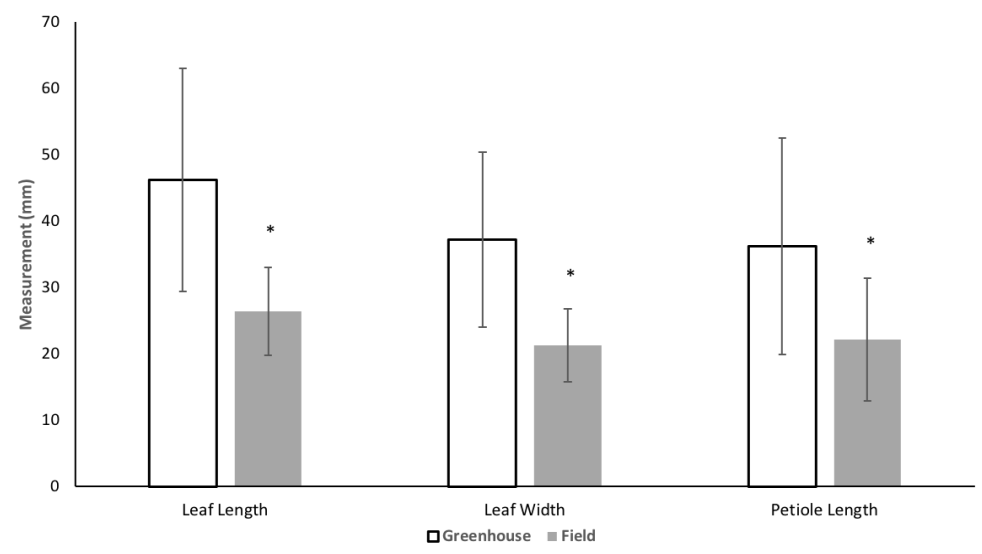

Fig 5 Growth was significantly different on the last day of observations with the greenhouse plants outperforming the field plants in terms of leaf size and petiole length. * denotes statistical significance among the greenhouse and field populations at $\mathbf{p}=\mathbf{0 . 0 5}$.

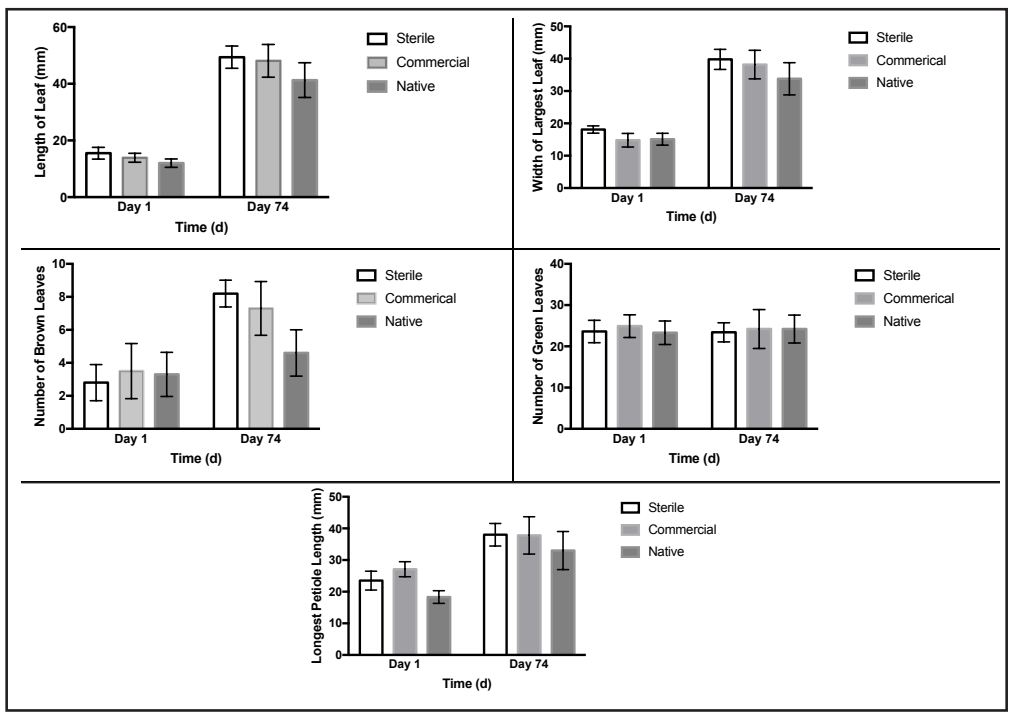

Fig 6 Results of two way repeated measure ANOVAs from all tested parameters on the first and last day of the greenhouse trial observations at the K.C. Irving Centre. Error bars depict the standard error of the mean. Three mycorrhizal treatments were tested: sterile, a native prepared inocula of Brier Island soil and a commercial inocula (MykePro WP). Redness scores were not included because the greenhouse plants did not display any signs of reddening over the course of the trial. 
population and Fig 7 for the field population. No significant difference was found among measured characteristics of plants for the native inoculum, commercial inoculum, or sterile treatments.

Roots from G. peckii plants growing in the K.C. Irving Centre Experimental Gardens at Acadia University were colonized by AMF. To our knowledge, this is the first time that AMF associations have been confirmed for $G$. peckii. Root colonization rates were low, at $20 \%$, but the sample size was just 100 root segments from four plants and the garden conditions were significantly different from the bog habitat on Brier Island.

AMF colonization rates of $G$. peckii plants on Brier Island are undetermined at this time, but are currently being assessed. A native AMF inoculum was produced in this study by using soil collected from under G. peckii on Brier Island, confirming that AMF are present in the natural substrate. The five greenhouse grown plants tested at the end of the growth season did not show any AMF when examined

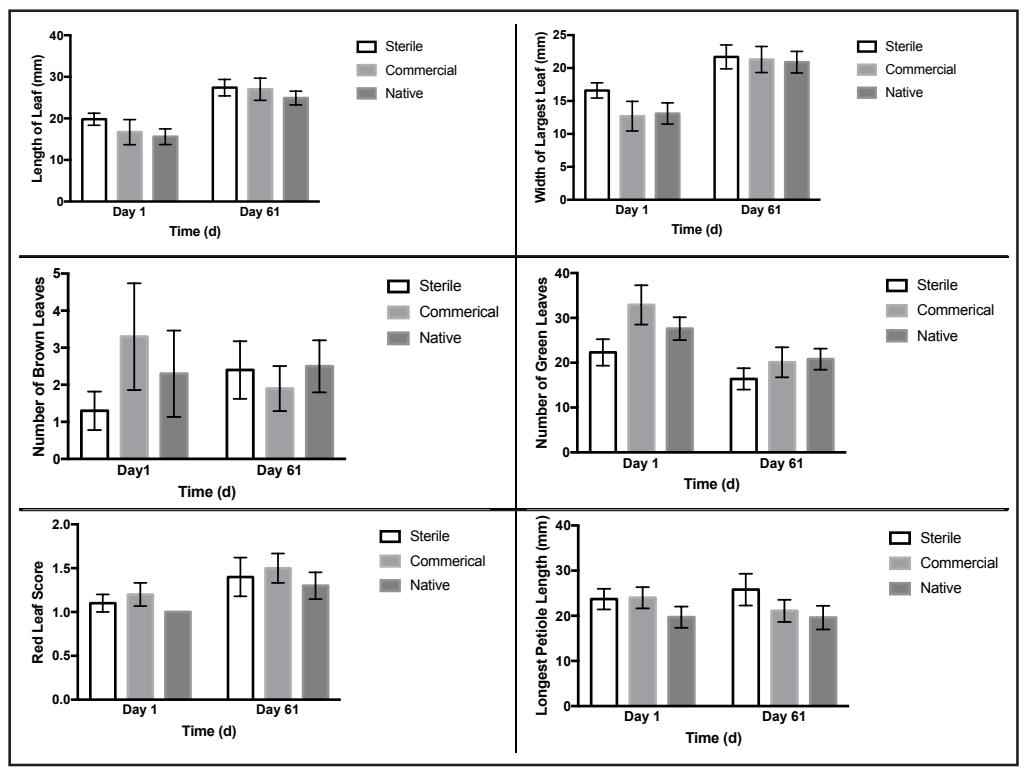

Fig 7 Results from two way repeated measure ANOVAs of all tested parameters on the first and last day of the $G$. peckii field trial observations. Error bars depict the standard error of the mean. Three mycorrhizal treatments were tested: sterile, a native prepared inocula of Brier Island soil and a commercial inoculum (MykePro WP). The red score native inoculum treatment does not have an error bar because all plants were given a ranking of one (little redness) on the first day of the 74 day trial. 
microscopically following staining. It is possible that the inoculation treatment was not effective for AMF colonization during the trial period. The low stress environment and nutrient availability in the greenhouse substrate could have negated the need for plants to form association with AMF (Smith and Read, 2008; Neuenkamp et al., 2018). Future evaluation of survival and testing for AMF colonization among the field plants is warranted. Based on the results from the first growing season, the hypothesis that introducing AMF inocula would aid in out-planting survival is not supported.

\section{CONCLUSIONS}

The Acadia University seed bank currently seeks to establish preservation, propagation and restoration strategies for eleven rare and endangered native Maritime plant species (Fancy, 2017). Results from the present study have confirmed that $G$. peckii seed can be retrieved from low temperature seed bank storage, germinated, multiplied through tissue culture and successfully out-planted under greenhouse and field conditions. Over the 2016 growth season, 100\% of field trial G. peckii survived and $97 \%$ of the greenhouse plants also survived. This is also the first time that G. peckii arbuscular mycorrhizal fungal associations have been confirmed.

Observation and monitoring of the field trial have continued in 2017-2019. With time and future studies, more insight can be expected with respect to G. peckii AMF associations. This may impact the methods used for the preparation of inocula and treatment of tissue culture plantlets at out-planting. This approach using seed banks and tissue culture could increase habitat reintroductions as part of an overall strategy for plant conservation and protected area management, and in the context of maintaining global biodiversity (Maunder, 1992; Maunder et al., 2004; Ayuso et al., 2019).

Acknowledgements The authors wish to thank Acadia students Sarah Adams, Lita O’Halloran, Sadie Moland, Kayoung Heo, and Riley Scanlon for foundational work in the Acadia University Seed Bank. Thank you to Dr. David Kristie and Phyllis Essex-Fraser for support in developing methods and troubleshooting during analysis and writing. Thank you to Dr. Nick Hill for the support in locating a field site on Long Island, and to Gini Proulx and Charlotte Rus- 
sell for field work support. For funding support, we would like to acknowledge the Arthur Irving Academy of the Environment, Blomidon Naturalists Society, and the Morton Centre Foundation. Thank you to the Nova Scotia Department of Lands and Forestry for granting a Scientific Permit to undertake this research.

\section{REFERENCES}

Adams, S. (2016). Foliar endophytic diversity of Eastern Mountain Avens, Geum peckii Pursh (Rosaceae), from degraded and pristine habitats in Digby County, Nova Scotia, Canada. Acadia University., Wolfville, NS. (Honours thesis).

Ayuso, M., Garcia-Perez, P., Ramil-Rego, P., Gallego, P., \& Barreal, M. (2019). In vitro culture of the endangered plant Eryngium viviparum as dual strategy for its ex situ conservation and source of bioactive compounds. Plant Cell, Tissue and Organ Culture 138(3): 427-435.

Bunn, E., Turner, S., Panaia, M., \& Dixon, K.W. (2007). The contribution of in vitro technology and cryogenic storage to conservation of indigenous plants. Australian Journal of Botany 55: 345-355.

Chandra, S., Bandopadhyay, R., Kumar, V., \& Chandra, R. (2010). Acclimatization of tissue culture plantlets: from laboratory to land. Biotechnology Letters 32: 1199-1205.

Convention on Biological Diversity. (2012). Global Strategy for Plant Conservation: 2011-2020. Botanic Gardens Conservation International, Richmond, UK.

COSEWIC. (2010). COSEWIC assessment and update status report on the Eastern Mountain Avens Geum peckii in Canada. Committee on the Status of Endangered Wildlife in Canada. Ottawa. vi + 11 pp.

Environment Canada. (2010). Species at Risk Act Recovery Strategy Series. Environment Canada, Ottawa, ON, Canada.

Fancy, S. (2017). Investigations of ex situ strategies for the conservation of Geum peckii (Eastern Mountain Avens). Acadia University, Wolfville, Nova Scotia. (Honours thesis).

Giovanetti, M. \& Mosse, B. (1980). An evaluation of techniques for measuring vesicular-arbuscular infection in roots. New Phytologist 84: 489-500.

Hill, N. (2016). June 11. Personal Communication. Long Island, NS.

Kumar, K., \& Rao, I.U. (2012). Morphophysiological problems in acclimatization of micropropagated plants in Ex vitro conditions: A review. Journal of Ornamental and Horticultural Plants 2(4): 271-283.

LaRue, D. (2016a). Natural regeneration of the globally rare Geum peckii (Rosaceae) on Brier Island, Nova Scotia. Rhodora 118(975): 310-314.

LaRue, D. (2016b). In situ and ex situ propagation of the globally rare Geum peckii (Rosaceae). Rhodora 118(975): 315-319. 
Makowski, D., Tomiczak, K., Rybczynski, J.J., \& Mikula, A. (2016). Integration of tissue culture and cryopreservation methods for propagation and conservation of the fern Osmunda regalis L. Acta Physiologiae Plantarum 38: 19.

Marriott, P., \& Sarasan, V. (2010). Novel micropropagation and weaning methods for the integrated conservation of a critically endangered tree species, Medusagyne oppositifolia. In Vitro Cellular \& Developmental Biology-Plant 46: 516-523.

Maunder, M. (1992). Plant reintroduction: an overview. Biodiversity and Conservation 1(1): 51-61.

Maunder, M., Havens, K., Guerrant, E., \& Falk, D. (2004). Ex Situ Methods: A Vital but Underused Set of Conservation Resources. Ex Situ Plant Conservation. Washington, DC: Island. Pp. 3-20.

Moland, S., Robicheau, B.M., Browne, R., Newell, R. \& Walker, A.K. (2018). Determining the effects of biochar and an arbuscular mycorrhizal inoculant on the growth of fowl mannagrass (Glyceria striata) (Poaceae). FACETS 3 (1):441-454.

Morton, J.B., Bentivenga, S.P., \& Wheeler, W.W. (1993). Germ plasm in the International Collection of Arbuscular and Vesicular- Arbuscular Mycorrhizal Fungi (INVAM) and procedures for culture development, documentation, and storage. Mycotaxon 48: 491-528.

Neuenkamp, L., Prober, S., Price, J., Zobel, M., \& Standish, R. (2018). Benefits of mycorrhizal inoculation to ecological restoration depend on plant functional type, restoration context and time. Fungal Ecology 40: 140-149.

Pence, V. (2011). Evaluating costs for the in vitro propagation and preservation of endangered plants. In Vitro Cellular \& Developmental BiologyPlant 47: 176-187.

Poirier, J. (2016). The relationship between water table depth and health of Eastern Mountain Avens (Geum peckii) on Brier Island, Nova Scotia. St Francis Xavier University, Antigonish, NS. (Honours thesis).

Rowntree, J.K., Pressel, S., Ramsay, A. Sabovijevic, A. \& Sabovijevic, M. (2011). In vitro conservation of European bryophytes. In Vitro Cellular \& Developmental Biology-Plant 47(1): 55-64.

Smith, S.E., \& Read, D.J. (2008). Mycorrhizal Symbiosis. 3rd ed. Boston: Elsevier.

Vierheilig, H., Coughlan, A., Urs, W., \& Piche, Y. (1998). Ink and Vinegar, a Simple Staining Technique for Arbuscular-Mycorrhizal Fungi. Applied and Environmental Microbiology 64(12): 5004-007. 